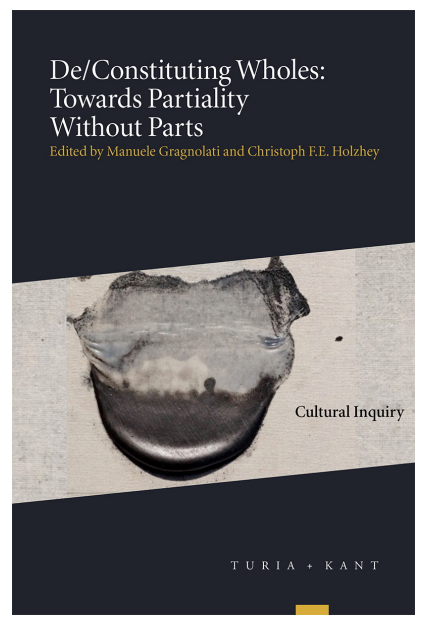

De/Constituting Wholes: Towards Partiality Without Parts, ed. by Christoph F. E. Holzhey and Manuele Gragnolati, Cultural Inquiry, 11 (Vienna: Turia + Kant, 2017), pp. 47-65

\section{RUTH PRESER (iD}

\section{Things I Learned from the Book of Ruth}

Diasporic Reading of Queer Conversions

CITE AS:

Ruth Preser, 'Things I Learned from the Book of Ruth: Diasporic Reading of Queer Conversions', in De/Constituting Wholes: Towards Partiality Without Parts, ed. by Christoph F. E. Holzhey and Manuele Gragnolati, Cultural Inquiry, 11 (Vienna: Turia + Kant, 2017), pp. 47-65 <https://doi.org/10.37050/ci-11_03>

\section{RIGHTS STATEMENT:}

(C) by the author(s)

This version is licensed under a Creative Commons AttributionShareAlike 4.0 International License. 


\title{
THINGS I LEARNED FROM THE BOOK OF RUTH
}

\author{
Diasporic Reading of Queer Conversions \\ Ruth Preser $^{*}$
}

In Borderlands/La Frontera, Gloria Anzaldúa recounted a discussion on homophobia held between members of faculty and students of an American college. ${ }^{1}$ Citing a straight Caucasian student who understood the term 'homophobia' as 'the fear of going home', ${ }^{2}$ Anzaldúa, a Chicana, lesbian, and feminist scholar, embraced the student's misconception, which emphasized not only the act of incitement but also its effects. While typically relating to a range of negative social attitudes, feelings, and practices, 'homophobia' in the Anzaldúan sense expands the term to account for the effects of this incitement, namely, the fear of going home, the fear of not having a home to return to, and the fear of being abandoned by one's own culture, community, and family. Anzaldúa's notion of homophobia accounts for mythic homeland and newly acquired foreignness. Haunted by displacement and loss, it resonates with diasporic longing, disorientation, and rapidly changing coordinates of belonging. Homosexuality, then, not only is a transformation in identification (as in 'I'm a lesbian'), which has a public, declarative, and performative bearing (as in 'coming out') but also generates shifts in time and space, an ongoing motion of departures and returns from one site to another, and so urges us to reflect on the contingency of queerness and migration, hospitality, and belonging.

This article is the outcome of a Tikkun Shavuot, a night of communal study in the Jewish tradition, held by 'Hamakom', a home for secular and cultural Judaism in Berlin, on May 2013, at which I presented a queer and diasporic reading of the Book of Ruth. It is a lucky stray from a research project on the Israeli queer diaspora in Berlin, supported by the Bar-Ilan University Oversees Postdoctoral Fellowship and hosted by the Institute for European Ethnology and the Gender Studies Program at Humboldt University Berlin, and the Postdoctoral Fellowship of the ICI Berlin Institute for Cultural Inquiry. Parts of this article were presented at the Institute for European Ethnology colloquia series and published as an essay in Theory and Criticism, 43 (2014), pp. 313-19, in Hebrew. I am grateful to Manuele Gragnolati and Christoph Holzhey, the editors of the collection, for their thoughtful and instructive comments. 
The Book of Ruth (or 'Scroll of Ruth'), is a biblical narrative that opens with two women: Naomi the Israelite, a bereaved wife and mother who wishes to return from Moab to Judea after the deaths of her sons and husband; and her no-longer-daughter-in-law, Ruth the Moabite, who pledges to follow Naomi, abandoning her gods and people, effectively turning her back on patriarchy and disregarding her gender roles - or so it seems. It is a tale of nomadic intimacies and speechacts of pledging and conversion, an iconic and laconic narrative, and a seminal text in Judaism that discusses issues such as exile, women's identification, conviviality, and kinship. Since it is not fully narrated but rather full of gaps, voids, and 'ghostly matters', ${ }^{3}$ the Book of Ruth provides apt ground and a malleable vessel for contemporary appropriation by stories seeking incarnation.

While the biblical narrative communicates a story of successful assimilation of the poor and the foreigner, a resolved 'homecoming', it is troubled by displacement, unresolved diasporic longing, and an acute sense of loss. Employing Anzaldúa's hom(e)ophobia and Avery Gordon's modality of haunting, my proposed reading of the Book of Ruth aims to understand contemporary forms of dispossession and their impact, especially when they are supposedly over and done with, and when their oppressive nature is denied. ${ }^{4}$ Such denials are reflected in the Zionist discourse of the establishment of the state of Israel, which concurrently echoes narratives of diaspora, exile, and homecoming, while rejecting and renouncing diaspora as a valuable and viable culture and existence for Jews. ${ }^{5}$ Violently replacing diasporic cultures and histories with a linear homecoming narrative, the Zionist ideology adopted by the state of Israel has forced a melting-pot policy onto the immigrating Jews, on the one hand, and a violent occupation and dispossession onto the Palestinian indigenous people, on the other hand. The 'melting-pot' has become an apparatus of conversion, performed by socialization agents such as immigration officials, school teachers, and the army, aiming at Hebraicizing the diasporic Jews by rejecting signs and practices that demonstrate the immigrants' attachment and engagement with their traditions and cultures. ${ }^{6}$ The rejection and negation of diaspora is a fundamental idea of Zionism, which constructs diaspora as an 'exile' that endangers the physical and spiritual existence of the Jewish people and can be overcome only by a 'homecoming' to Israel. ${ }^{7}$ 
Nevertheless, diaspora and displacement still pulsate in current Jewish-Israeli culture. The nationalist approach to diaspora has been criticized by post-Zionist discourses that associate the negation of diaspora with Zionism's indifference to the suffering of diasporic Jews during the Holocaust, the negation of Palestinian national identity and the infringement of their individual rights, as well as the erasure of the Mizrakhi cultural heritage while marginalizing Mizrakhi people (Jews from Arabic-speaking or Muslim countries). ${ }^{8}$ The massive Jewish immigration to Israel in the 1950 s created a bifurcated social structure in which Mizrakhi Jews were subordinate to Ashkenazi (European, primarily East European) Jews. The Ashkenazi domination of Jewish Israeli society was acquired through the 'orientalization' of Mizrakhi Jews, which employs a previously existing East/West dichotomy to advance a binary construction of ethnicity and simplifies the heterogeneity of the cultures into two homogenous categories: Ashkenazi Jews, who are fully 'Western', and Mizrahi Jews, who are fully 'Eastern'. This binary has shaped and justified unequal distribution of resources and led to the entrenchment of ethnic division. ${ }^{9}$ Yet it is not only the diaspora that is rejected but also the geo-cultural context in which the state of Israel was established. A derogatory attitude towards the Arab or Muslim heritage of Mizrakhi Jewry is the view of the political mainstream in Israel, whose ardent desire is to live in a Jewish state cleansed of Arabs or of Arab culture altogether. ${ }^{10}$ Proscribing against the mixing of Arabs and Jews, either in practice or in language and culture, the Zionist ideology rejects the idea of association between Israel and Israeli culture and anything that could be considered Arab, as differentiated from Jews who could be considered European. ${ }^{11}$ Consequently, the Israeli culture machines have carried out a practice known as de-Arabization, which mainly entails the erasure of history, language, and culture. ${ }^{12}$

Current critique of the Zionist negation of diaspora, such as the works of Aziza Khazzoom, Adi Kuntsman, Amnon Raz-Krakotzkin, and Raz Yosef, advocates diaspora as a hybrid, flexible, changing, non-linear and anti-essentialist Jewish cultural identity, which may exist and persist even after 'homecoming'. This critique opposes teleological discourses that underscore concepts of origin, displacement, and return. Instead of establishing a mythical and organic connection to land and nation, and focusing on a symbolic and concrete idea of 'return', this critique focuses on the act, experience, and effects of dis- 
placement, rejecting categories of nation and underscoring the significance of routes rather than roots. ${ }^{13}$ Furthermore, it reveals that the logic of negation is dependent upon racial and national discourses of origin and purity and is backed up by heterosexual formations of gender and sexuality and by heteronormative structures of kinship. ${ }^{14}$ In order to critically address both the genealogical implications of diaspora as well as questions of race, colonialism, and migration, Gayatri Gopinath has suggested that diaspora needs queerness as much as queerness needs diaspora:

This framework 'queers' the concept of diaspora by unmasking and undercutting its dependence on a genealogical, implicitly heteronormative reproductive logic. [...] Suturing 'queer' to 'diaspora' recuperates those desires, practices, and subjectivities that are rendered impossible and unimaginable within conventional diasporic and nationalist imaginaries. ${ }^{15}$

The Book of Ruth, which both assumes and subverts the linear logic of genealogy, conversion, and return, provides an opportunity to explore the unimaginable, the unresolved, and the impossible, namely diaspora as a spectre, rather than as an ontological entity and causal narrative. The spectre of diaspora relates to Gordon's notion of haunting as the process through which a repressed or unresolved social violence makes itself known and demands our attention: 'when home becomes unfamiliar, when your bearings on the world lose direction, when the over-and-done-with comes alive, when what's been in your blind spot comes into view'. ${ }^{16}$ The appearance of spectres notifies us, argues Gordon, that 'what's been concealed is very much alive and present, interfering precisely with those always incomplete forms of containment and repression ceaselessly directed toward us'. ${ }^{17}$

It is not surprising then that feminist and lesbian scholars, activists, and writers have been returning to the Book of Ruth. ${ }^{18}$ This biblical narrative has captured the attention of postcolonial feminist critics precisely because it captures the intersection between gender, ethnicity, class, race, and sexuality in cultural contacts and border-crossings. ${ }^{19}$ Refusing any methodological and ontological differentiation between fiction and fact, absence and presence, past and present, and present and future, ${ }^{20}$ this article proposes a queer and diasporic reading of the biblical text in the hope of contributing to scholarly debates on the intersection between queer theory and critical diaspora studies in the 
context of Israel/Palestine and against the backdrop of current inflammatory debates on the 'place of the Jew', to paraphrase Daniel Boyarin and Jonathan Boyarin. ${ }^{21}$

Not wishing to use 'queer' and 'diasporic' interchangeably, my investigation is troubled by questions of race, nomadism, and sexuality, asking what kind of theory might emerge if we examine 'home' through categories of movement rather than destination. Indeed, as has Gopinath asserted, the convergence of 'queer' and 'diaspora' unsettles the gender and sexual ideologies of nationalist domination and the genealogical reproductive logic they depend upon. ${ }^{22}$ Complicated by notions of cosmopolitanism and multiculturalism in an era when (some) bodies may traverse national borders and where (some) cities endorse queerness, my investigation asks what happens to bodies that continuously signify and become the bearers of diversity. ${ }^{23}$

The Book of Ruth is one of the shortest books in the Bible, recounting a story of love and devotion between women who are no longer bound by formal kinship ties. Ruth the Moabite pledges faith to her former mother-in-law, Naomi the Israelite, and follows her back from the kingdom of Moab to the land of Judea. Juxtaposing the established cultural hegemony with the social and ethnic margin, the Scroll gives voice to the subclass, embodied in Ruth, who is thrice a stranger by virtue of her ethno-religious origins, gender, and socioeconomic status. ${ }^{24}$ The commitment and prioritization of female intimacy in the Scroll makes the narrative ripe for appropriation by lesbians. It is not surprising then that the organizers of the Third Lesbian Conference held in Natanya, Israel in 2004 chose the opening of Ruth's pledge to Naomi 'Wherever you go, I go' as the inscription on the conference $\mathrm{t}$-shirts. The Scroll is moreover used by both proponents and opponents of same-sex marriage in the debate raging in the United States. ${ }^{25}$

The urgent need to read queer desire and lesbian lives in canonic and hegemonic texts echoes one of the earliest strategies of feminist textual reading, such as in the case of 'palimpsest' reading. ${ }^{26}$ This term, coined by Sandra Gilbert and Susan Gubar in the context of female writing and reading of gothic novels, suggests that all women's texts are palimpsests: 'They mask secret subtexts of desire, politics and meaning. While their "surface" meanings might be those that were acceptable during their time, the palimpsest reveals something else altogether. ${ }^{27}$ Interpreting the Book of Ruth plays the same role - namely, a lesbian reading between the lines in Western cultures, looking for role models 
where all traces were hidden. ${ }^{28}$ Turning to the Bible as a canonic text in the Jewish and Israeli context makes sense: in Israel, separation between state and religion simply does not exist, and national belonging and ethnic or cultural affiliation are indistinguishable in institutional and national discourses. Consequently, it does not matter if one identifies as a practicing Jew, a cultural Jew, or as an 'automatic' Jew, namely born into this ethnic group, its rites, and mythologies. Though it is not within the scope of this article to distinguish between or make a claim to coherent forms of Jewish identity, it is important to stress that when using the formation of 'cultural Jew', I relate to queer scholarship, such as the efforts of Daniel Boyarin and Jonathan Boyarin as well as Judith Butler, to reflect on modes of cultural belonging that are not restricted to religious practices and/or national citizenship. ${ }^{29}$

The Book of Ruth does not detail the relationship between Ruth and Naomi; it simply presents us with an exceptional story of devotion. It reverberates Adrienne Rich's notion of woman-identification and a lesbian existence, which exceeds the boundaries and norms of heteronormative kinship. ${ }^{30}$ Cautious not to apply an anachronistic conception of lesbianism to the text, queer scholars seem to agree that the RuthNaomi dyad offers a powerful biblical example of same-sex intimacy. ${ }^{31}$ As I show in what follows, this dyad is eventually utilized by the institution of heterosexuality, yet the route is so queer, so subversive, that it cannot be read in a linear and simplistic manner as either subversion or assimilation. Furthermore, the Book of Ruth complicates the notion of home as a private sphere of warmth and comfort by urging us to conceive of 'home' and its making as a national, ethnic, gendered, and legal category that bears consequences in regards to citizenship. My reading then relates to 'home' not merely as a site but as a motion, something that sets you on your way, neither as an origin nor as a destination but rather as an 'Ithaca', to borrow C.F. Cavafy's reading of an ambiguous homecoming. ${ }^{32}$ Hence, in my reading of the Scroll, home is not a fixed and stable location but a destabilizing and contingent construction, which entails movement, seeking, and negotiation. ${ }^{33}$

My engagement with Ruth occurred serendipitously. I was in the midst of an ethnographic research period, investigating the Jewish Israeli lesbian diaspora in Berlin, when I was invited to give a 'Teaching', namely, to lead participatory learning on the occasion of Tikkun, a night of communal study on the Jewish Holiday of Shavuot. The event was held by 'Hamakom' - a home for secular and cultural Juda- 
ism in Berlin - which meant I was free to engage with the scriptures without the constraints of formal orthodoxy. As the Book of Ruth is the text read on the morning of Shavuot, and as I was deeply affected and inspired by Michal Ben Naftali's deconstructive reading and Orit Kamir's feminist reading of the biblical narrative, I set to prepare a 'teaching' and to rethink the story I knew already so well. ${ }^{34}$ This time, however, I was to approach the narrative from the perspective of a temporary migrant and a diasporic subject - although a privileged one. My privilege stems from being able to choose to live openly as a lesbian and being able to choose to relocate, even if temporarily, to the city that has become in the past decade a queer cultural homeland, a 'New Zion', ${ }^{35}$ a site of longing for emancipation from nationalistic violence and a relief from the impossibly high cost of living in Israel, for straights and queers alike. This communal teaching allowed me to return once again to the Book of Ruth from a queer and diasporic perspective, while residing 'outside' the nation.

\section{EXILE}

The high cost of living, the erosion of economic capacity, and the impossibility of leading a dignified life may also have set in motion the biblical plot of Ruth. Naomi and Elimelech, an Israelite couple struggling to make ends meet, leave Bethlehem and, together with their sons Mahlon and Chilion, turn eastward towards the kingdom of Moab. There, they settle and make a home; there, Mahlon and Chilion marry local women, Orpah and Ruth; and there, Elimelech and his sons die, leaving behind three widows. The three women are bound through marriage ties that no longer exist, and nonetheless, Ruth and Orpah refuse to dissolve the relationship and to part from Naomi. This mode of relationality might be described in a queer context as a 'family of choice', a term coined by Kath Weston to portray kinship practices and feelings that do not depend on biological filiations and are not based on reproduction, ${ }^{36}$ as no children were born to Ruth and Orpah from their marriages to Naomi's sons. Yet these three women form a family, one that exists without institutional contracts, formal rites, or public recognition. Orpah and Ruth, no longer connected by law, refuse to return to their mothers' households, remarry, and bear children. Such an 'alternative' kinship structure - in which women hold onto each other and 
refuse to separate, to prioritize patriarchal gender roles, or to favour their own people, families, and gods - both materializes and collapses in this biblical narrative. In a social context in which women must rely upon the men in their families or ethnic communities, where geopolitical belonging - today we might describe it as a passport or visa demarcates life from death, Naomi, a bereaved and impoverished woman, wants to go home. Orpah and Ruth are determined to follow her, perhaps due to their young age or because their bereavement is not as overwhelming as Naomi's. Or perhaps their determination is due to the fact that they have not yet experienced migration and displacement and cannot envisage the effects of being an 'other', foreign to the culture, removed from its rituals, depending on a whim of hospitality towards strangers that is not anchored in laws and regulations. ${ }^{37}$ Convinced by Naomi to return to her mother's household, Orpah bids farewell, whereas Ruth turns her back on her gods, her home, and patriarchy altogether, or so it seems, and follows Naomi on the journey to Judea.

We do not know what happened during the journey, and we do not know what Ruth's pledge instigated or what her words sparked, once she uttered:

Entreat me not to leave thee, or to return from following after thee: for whither thou goest, I will go; and where thou lodgest, I will lodge: thy people shall be my people, and thy God my God: Where thou diest, will I die, and there will I be buried: the Lord do so to me, and more also, if aught but death part thee and me. ${ }^{38}$

Were Ruth and Naomi awakening to a potential that had never occurred to them, to the possibility to love each other in ways that transgress the relationship between mother-in-law and daughter-inlaw? After all, Naomi called Ruth 'my daughter'. But so did Boaz, later in the Scroll, and then he impregnated her. Was Naomi alarmed, ambivalent, pushing Ruth back and forth indecisively? Or did she allow herself to be persuaded? Perhaps she decided that she will allow this to continue, but only on their journey from Moab to Judea, only until they get 'home'. ${ }^{39}$ Did Naomi know already what would await them in Bethlehem? Did she appraise the burden of surviving as a poor widow with her foreign daughter-in-law with no legal claim on her deceased husband's property, as neither she nor Ruth had a son who could function as the name bearer and legal heir? Could she predict the limits of toler- 
ance and acceptance for their strange dyad? Did Naomi foresee Ruth's potential role in acquiring a dignified life and securing their access to property and belonging?

Or perhaps the sudden and unexpected outburst of life - so much life! - granted Naomi a temporary disruption from the heavy grief over her sons and husband, from the scorching anger over a future that portends horrifying poverty, and from a return to a community that she may never have considered returning to. Was it precisely this interruption of the pain at the loss of a home and the fear of going home that enabled Naomi to hope or even imagine a queer existence of shared lives and emotional and economic sustainability that would free her from dependency on men and patriarchy, now that her children were gone and her womb had dried out? Did she share her thoughts with Ruth, whispering in her ear during those nights in the wilderness, next to a campfire? Or did they share an unspoken contract, ${ }^{40}$ a foreseen chronicle of separation, sealed between the one who pledges and the one who remains silent? And perhaps this is our constitutive lesbian meta-narrative, the mythos, script, and scripture of lesbian separation. ${ }^{41}$

And then they arrived, and publicness and outness, which seem to be desired by queers and which are also known as the politics of recognition and visibility, swooped down on them. The people of Bethlehem instantly identified Naomi. Did she pale? Did she freeze once the women identified Ruth as 'thy daughter-in-law, which loveth thee', ${ }^{42}$ using a verb rarely used in the Bible. ${ }^{43}$ Or perhaps she was relieved once an acceptable interpretation was adopted by the curious crowd, namely a story of devotion and respect of a former daughter-in-law to her elder, portraying respectable kinship ties and identifying Ruth as 'better to thee than seven sons'. ${ }^{44}$ 'Better than seven sons' constructs a storyline of mutual devotion and nourishment during times of grief and loss - a narrative that restored the good order and normative scripts of intergenerational relations. This construction lent coherence and intelligibility to the strange dyad of Naomi and Ruth and secured their return home. 


\section{ARRIVAL}

And so it began, the attempt to survive under the beating sun. Day after day, Ruth follows the reapers in the field, gleaning ears of corn; and night after night, back with Naomi, she dwells in their desperate poverty. It is harvest season, and the fields in which Ruth gleans the leftovers belong to Boaz, a kinsman of Naomi's late husband, 'a mighty man of wealth'. ${ }^{45}$ Boaz, a generous landlord, full of grace, instructs his reapers to let Ruth 'glean even among the sheaves' and not just mere leftovers. He charges the young reapers not to touch her, offering Ruth his protection, and sustaining her with water from his men's vessels and with bread and vinegar. ${ }^{46}$

It is important to note that the Pentateuch sets clear instructions regarding charity and duties towards the poor during harvest time. These instructions are embedded in reminders of histories of displacement, work migration, and diasporic conditions: 'And you shall remember that you were a slave in the land of Egypt. ${ }^{47}$ Thus, the Israelite landowner must both purposely leave parts of his field unharvested ${ }^{48}$ as well as relinquish forgotten sheaves rather than returning to collect them. ${ }^{49}$ Performing acts of generosity that exceed the law, Boaz's compassion serves as a powerful reminder of the realities encountered by young, poor, migrant women while being exposed to famine and sexual abuse - a palimpsest that discloses that the straits might actually be direr than suggested by the Pentateuch and that a landowner might be less generous and more harmful.

For sure, Boaz was their deliverance, and so the plan to seduce him - a kinsman with the power and authority to help Naomi redeem her land - is prescribed in such a narrative. Indeed, it took Naomi but ten verses to plot a rescue for Ruth and herself, ten verses before she instructed Ruth:

Wash thyself therefore, and anoint thee, and put thy raiment upon thee, and get thee down to the floor: but make not thyself known unto the man, until he shall have done eating and drinking. And it shall be, when he lieth down, that thou shalt mark the place where he shall lie, and thou shalt go in, and uncover his feet, and lay thee down; and he will tell thee what thou shalt do. And she said unto her, All that thou sayest unto me I will do. ${ }^{50}$ 
Ruth dutifully submits to the patriarchal order, consenting to seduce a wealthy landowner and bear his son in order to find a legal outlet (though a dubious and nonlinear one) that will restore kinship ties between Ruth and Naomi and keep Elimelech's land in their possession. This restoration is possible through Boaz, a living kinsman of the deceased Elimelech and his son Mahlon, Ruth's late husband. It is a return to a masculine genealogy that materializes in and through a womb, a conspicuous surrogacy involving two fathers and two mothers. On the one hand, Boaz is the biological father, the provider of semen, and Mahlon is the name-giver who ties the newborn to land, nation, and family, while on the other hand, Ruth and Naomi are the surrogate mother (and egg donor) and her lover. ${ }^{51}$ This project of belonging is orchestrated and plotted by Naomi, whose entrepreneurial spirit turns her, at least symbolically, into an impregnator and thus, perhaps, a 'father'. As Mahlon's mother, she is in fact the grandmother, at least according to normative kinship structures, but at the end of the Scroll, she acts as a nurse: 'And Naomi took the child, and laid it in her bosom, and became nurse unto it. ${ }^{52}$

Indeed, even if Naomi is not the biological mother, she is the one who receives the baby who will allow her to complete the act of return and to belong, which means to redeem land, establish a house and lineage, and finally, come home. Motherhood always does that to us, doesn't it, to straights and lesbians alike, facilitating a 'return home', restoring a long-lost intelligibility, which is reinstated once we carry a child in our wombs. Although the narrative reproduces and enforces the norm, the route is so queer and thwarting that it does not adhere to scriptural legal standards, either for establishing kinship ties or for redeeming the land. ${ }^{53}$

\section{WHEN HOME BECOMES UNFAMILIAR}

And Ruth, what about Ruth? How can we perform a feminist and queer reading of Ruth's absent narrative, a tale of arguable rape, of trafficking in human organs, of seducing a wealthy man in order to survive, in order to belong? What if she did not want a child? What if she did not want to be a mother? Orpah returned to her people and gods, namely to normative gender roles, but not Ruth. Ruth pledged that she would be buried next to Naomi, a clear and unequivocal statement 
regarding her intentions to never get married, as a married woman would be buried on her husband's estate. ${ }^{54}$ But on the other hand, it may have been a relief for Ruth to find an outlet, a solution that would provide the means to continue living next to Naomi.

Perhaps she thought to herself:

It will calm Naomi down, calm her fears of poverty; it will grant us economic sustainability, the redeemed land. She wants a child, god knows why, and I want her.

Perhaps they discussed it at night, plotting together. Perhaps Ruth said:

I don't want a child, I want you.

Perhaps Naomi answered:

I'll raise him. It won't hurt your freedom.

Perhaps she also added:

Without this, they will never accept you. You will always be a foreigner. You've seen how they gaze at you, how they react to your accent, pretend not to understand you. They will never let us be, and I will not be able to protect you forever. There's a system; let's take advantage of it!

Perhaps Ruth was silent for a while, then perhaps she said:

Let me think about it for a bit.

In current terms and context, Orit Kamir has asserted that we can reframe their situation as follows: Naomi is an immigrant from the former USSR, a Jew according to Jewish law, coming to Israel with her widowed Russian daughter-in-law. ${ }^{55}$ The former daughter-in-law tries to undergo a naturalization process but finds herself butting up against the Israeli Law of Return, which grants citizenship to non-Jewish spouses of Jews but not to a Jew's non-Jewish widow or widower. May we assume that the speedy conversion that Ruth the Moabit underwent - by merely pledging 'thy people shall be my people, and thy God my God" $^{56}$ — demonstrates a different, more humanist approach to the migrant and the vulnerable in society? Indeed, the story of Ruth reverberates even to the present day, and her name was given to an NGO that assists interreligious couples in Israel. ${ }^{57}$ 
Perhaps this biblical conversion demonstrates a diasporic consciousness, which reflects the compassion and empathy of the Israelites of Judea - a norm that was sustained despite their sovereign power and conjugation of genealogy and territorialism. ${ }^{58}$ Perhaps something from the story of Abraham, yet another Jewish nomad and displaced person, or the memory of exile in Egypt as an enslaved ethnic group was kept alive - an existential reminder that pulsates in the diaphragm. Perhaps these memories shaped the attitudes of the Israelites of Bethlehem towards nomads, refugees, the Other - towards this strange woman who insisted on performing the Fifth Commandment of honouring her mother, even when she was free to leave. Perhaps the people of Judea acknowledged a heterogeneous existence in complex reality, ${ }^{59}$ where hunger, love, or even prophetic visions create a motion, make borders more penetrable, and hybridize concepts of citizenship and belonging. Perhaps the people of Judea fully participated in the cultural and geopolitical life of their region and thus could appreciate the yearning to leave and the longing to return. Perhaps this story of Ruth and Naomi is a remnant of a Jewishness that is not territorial, as it continues and exists anywhere, even in Moab, and that is not genealogical, as anyone may convert and belong. ${ }^{60}$ Perhaps, as Boyarin and Boyarin assert, there is such a consciousness within a people that has been chronically unconnected with a particular land, a people that calls into question the idea that a people must have a land in order to be a people; a people that was born in exile and migrated, fled, has been dislocated and de-territorialized, over and over again, with a European passport and without, a people that has produced its cultural formation within conditions of diaspora and stubbornly hung on to ethnic and cultural specificity but in a context of deeply felt and enacted human solidarity. ${ }^{61}$ Or was it the case of a people, as Amnon Raz Krakotzkin has maintained, that acknowledged that the existential state of humanity is not redeemed, neither in Judea nor beyond? ${ }^{62}$

But does the hospitality of the people of Judea alleviate the sting of rape and trafficking? Can free consent truly exist in a context of migration and economic dependency? I do not have a categorical answer. Yet am I comfortable with a reading of $R u t h$ that proposes her unequivocal victimization and the annihilation of agential capacity? I do not know that either, for this story repeats itself every day and every hour, in those households where a woman is biting her fingernails, contemplating how to survive if she leaves, how to breathe if she stays. As if such a 
place and time existed, one that grants ultimate freedom from power, where choice can be exercised without consequences. Feminist readings of Ruth interpret her actions as both active and agential: for example, some see Ruth as forcing her way into Naomi's community. At the same time, these readings recognize the ambiguous identity of foreign women who attempt to assimilate into cultures that view outsiders with suspicion while simultaneously commodifying their labor and reproductive potential. $^{63}$

\section{WHERE IS RUTH?}

The womb was Ruth's conversion, her recognition and acceptance terms that are nothing if not familiar in LGBT politics. Even today, the Book of Ruth is provided as an exemplar of humane and compassionate conversion with a happy ending, and it is used to demonstrate the capacity of Judaism to welcome foreigners. Indeed, many women who marry men of Jewish background and convert to Judaism take the name Ruth as their Hebrew name, as Ruth was the first woman in the Bible to convert to Judaism. ${ }^{64}$

Did Ruth herself mean to convert out of belief in God? Or did she embrace whatever one embraces when one loves another person, her God, her people, her semen? ${ }^{65}$ Did Naomi and Ruth separate? Was there yet another story of exile and migration? Did Ruth's heart skip a beat once they entered the gates of Bethlehem and Naomi resumed calling her 'daughter'? Did something change in the way Naomi moved around her? Did she start losing her temper over small issues? Were there silences or intensifying arguments, sudden sharp comments about Ruth's clothes or the way she did things, a nasty word here and there? Perhaps this made Ruth understand that they had arrived home, and home was also the eradicator of love. ${ }^{66}$ Did Ruth stay with Naomi hoping that something would change, or was it out of allegiance, a stubborn holding to one's own pledge? Is diaspora a structure of feeling, an unqualified intensity demanding a reading that admits the flesh and avows that history is written on and felt with the body, ${ }^{67}$ 'a what-couldhave-been, struggling for material expression and psychic form'? ${ }^{68}$

It may seem that the destination of conversion is where the narrative of transformation ends or becomes unnecessary, and where life begins; this emphasizes a linear temporality of progress, truth, and 
transformation. ${ }^{69}$ Yet the lingering intensity of the 'what-could-havebeen' has room in the logic of conversion, which calls attention to the fact that the demand for one identity (or perhaps one desire) does not preclude the existence of others but in fact requires them. ${ }^{70}$ In her reading of the Book of Ruth, Ben Naftali has applied a feminist autobiographical and deconstructive mode of voice-over to the biblical story. Ben Naftali's first-person voice-over brings forth another possible story. This proposed narrative does not produce any cohesion, unity, coherence, or autonomy. Rather, it points to the unresolved split between author and authored in autobiography, problematizing the idea that the destination of conversion is where the narrative of transformation ends and where 'real' life begins, destabilizing any linear temporality of progress, truth, and authenticity. ${ }^{71}$

Susanna Radstone has maintained that the distinction between author and authored is one of the fundamental elements of transformation narrative in a conventional first-person narrative, whereby a story about self-transformation is produced by emphasizing the 'then' of the story/protagonist and the 'now' of the author/narrator. This transformation, or becoming, arguably produces a character in process, a subject 'on her way.' ${ }^{72}$ Yet as both Daniel Barber and Radstone have noted, narratives of conversion, becoming, or transformation demonstrate a redemptive futurity as well as its refusal, caught in movement. ${ }^{73}$ These narratives leave us with ghostly markers highlighting an alternative epistemological and ontological framing, one that allows the psychic lives of Ruth and Naomi a livable and habitable terrain on which their relationship could survive. ${ }^{74}$

What happened then to Ruth after she gave her son, Obed, to Naomi? Did she stay, or did she leave? Did she experience relief, or did she feel sorrow? The Scroll ends by disregarding Ruth and Naomi; it restores the norm by declaring Obed's descendants through to King David. Yet in a way that is similar to Butler's reading of Antigone, Ruth may not 'achieve another sexuality, one that is not heterosexuality, [but] she does seem to de-institute heterosexuality by refusing to become a mother and a wife, by scandalizing the public with her wavering gender'. ${ }^{75}$

The haunted genealogy from Mahlon to king David, which is interrupted by deaths in a foreign land and restored by a lesbian existence, bends every single conventional rule of kinship and property, and with reference to Butler's reading, we might say that its position is not a posi- 
tion that is generally accorded social intelligibility, and yet it shows what kinship might continue to signify outside of conventional constraints. ${ }^{76}$ Ruth and Naomi's son Obed is the grandfather of King David, the second king of the united Israelite kingdom of Israel and Judea - a linage that according to biblical tradition will produce the Messiah - but this is a people and a kingdom established through a queer tale, constituting a home that by no means can be reduced to a geopolitical entity but rather underscores kinship and diaspora as affective and temporal processes; ${ }^{77}$ traces that demand repeated telling, interpretation, and return.

\section{NOTES}

1 Gloria Anzaldúa, Borderlands/La Frontera: The New Mestiza (San Francisco: Aunt Lute Books, [1987] 2012).

2 Ibid., p. 42.

3 Avery F. Gordon, Ghostly Matters: Haunting and the Sociological Imagination (Minneapolis: University of Minnesota Press [1993] 2008).

4 Gordon, Ghostly Matters, p. xv.

5 See Aziza Khazzoom, 'The Great Chain of Orientalism: Jewish Identity, Stigma Management, and Ethnic Exclusion in Israel', American Sociological Review, 68.4 (2003), pp. 481-510; Adi Kuntsman, Figurations of Violence and Belonging: Queerness, Migranthood and Nationalism in Cyberspace and Beyond (Peter Lang: Oxford, 2009); Amnon Raz-Krakotzkin, 'Exile within Sovereignty: A Critique of the Negation of Exile', Parts I \& II, Theory and Criticism, 4 \& 5 (1993/94), pp. 6-23 / 113-32 (Hebrew); Raz Yosef, 'Melancholic Attachments: Diaspora, Ethnicity, and Sexuality in Contemporary Israeli Cinema', Israeli Sociology: A Journal for the Study of Society in Israel, 15.1 (2013), pp. 11-34 (Hebrew).

$6 \mathrm{Oz}$ Almog, The Sabra: The Creation of the New Jew, trans. by Haim Watzman (Berkeley: University of California Press, 2000).

7 Yosef, 'Melancholic Attachments', p. 12.

8 Ibid., p. 11.

9 Khazzoom, 'Chain of Orientalism', pp. 481-82.

10 Yehouda Shenhav and Hannan Hever, “"Arab Jews” after Structuralism: Zionist Discourse and the (De)formation of an Ethnic Identity', Social Identities, 18.1 (2012), pp. 101-18.

11 Ibid., pp. 102, 105.

12 Ella Shohat, 'Sephardim in Israel: Zionism from the Standpoint of Its Jewish Victims', Social Text, 19/20 (1988), pp. 1-35 cited in Shenhav and Hever, Arab Jews, p. 108.

13 Yosef, Melancholic Attachments, p. 12. 
14 See Yosef, Melancholic Attachments; and Michael Gluzman, 'Longing for Heterosexuality: Zionism and Sexuality in Herzl's Altneuland', Theory and Criticism, 11 (1997), pp. 145-62 (Hebrew).

15 Gayatri Gopinath, Impossible Desires: Queer Diasporas and South Asian Public Cultures (Durham: Duke University Press, 2005), pp. 10-11.

16 Gordon, Ghostly Matters, p. xvi.

17 Ibid.

18 See among others Michal Ben Naftali, Chronicle of Separation: On Deconstruction's Disillusioned Love (Tel-Aviv: Resling, 2000) (Hebrew); Orit Kamir, "A "Law and Film" Analysis of The Book of Ruth and the Film Antonia's Line', Alei Mishapt Law Review, 8 (2010), pp. 55-132 (Hebrew); Kwok Pui-lan, Postcolonial Imagination and Feminist Theology (Louisville: Westminster/John Knox Press, 2005); Carolyn J. Sharp, 'Feminist Queries for Ruth and Joshua: Complex Characterization, Gapping, and the Possibility of Dissent', Scandinavian Journal of the Old Testament: An International Journal of Nordic Theology, 28.2 (2014), pp. 229-52.

19 Kwok, Postcolonial Imagination, p. 101.

20 Gordon, Ghostly Matters, p. xvii.

21 Daniel Boyarin and Jonathan Boyarin, 'Diaspora: Generation and the Ground of Jewish Identity', Critical Inquiry, 19.4 (1993), pp. 693-725.

22 Gopinath, Impossible Desires, p. 10.

23 Sara Ahmed, 'Multiculturalism and the Promise of Happiness', New Formations, 63 (2008), pp. 121-37.

24 Nehama Aschkenasy, 'Reading Ruth through a Bakhtinian Lens: The Carnivalesque in a Biblical Tale', Journal of Biblical Literature, 126.3 (Fall, 2007), pp. 437-53.

25 Lesleigh Cushing Stahlberg, 'Modern Day Moabites: The Bible and the Debate about Same-Sex Marriage', Biblical Interpretation, 16 (2008), pp. 442-75.

26 Sandra M. Gilbert and Susan Gubar, The Madwoman in the Attic: The Woman Writer and the Nineteenth-Century Literary Imagination (New Haven: Yale University Press, [1979] 2000).

27 Pramod K. Nayar, Contemporary Literary and Cultural Theory: From Structuralism to Ecocriticism (New Delhi: Pearson, 2010), p. 96.

28 Madipoane Masenya, 'Rebecca Alpert's Lesbian Reading of the Book of Ruth within the Context of Lesotho', Journal of Gender and Religion in Africa, 18.1 (2012), pp. 43-62 (p. 45).

29 Boyarin and Boyarin, 'Diaspora'; Judith Butler, Parting Ways: Jewishness and the Critique of Zionism (New York: Columbia University Press, 2012).

30 Adrienne Rich, 'Compulsory Heterosexuality and Lesbian Existence', Signs: Journal of Women in Culture and Society, 5.4 (1980), pp. 631-60.

31 Heather Hendershot, 'Holiness Codes and Holy Homosexuals: Interpreting Gay and Lesbian Christian Subculture', Camera Obscura, 15.3 (2000), pp. 150-93 (p. 172). 
32 Constantine P. Cavafy, The Canon, trans. by Stratis Haviaras (Athens: Hermes Publishing, 2004).

33 Kwok, Postcolonial Imagination, p. 102.

34 Ben Naftali, Chronicle of Separation; Kamir, 'Law and Film'.

35 Lawrence Schimel, 'Diaspora, Sweet Diaspora: Queer Culture to Post-Zionist Jewish Identity', in PoMoSexuals Challenging Assumptions About Gender and Sexuality, ed. by Carol Queen and Lawrence Schimel (San Francisco: Cleiss Press, 1997), pp. 163-73.

36 Kath Weston, Families We Choose: Lesbians, Gays, Kinship (New York: Columbia University Press, 1991).

37 The Pentateuch includes laws obligating kindness to strangers/foreigners. For example, 'Do not oppress a stranger, for you know the heart of a stranger, for once you were strangers in the land of Egypt' (Exodus 23:9, The Holy Bible, King James Version (New York: American Bible Society, 1999; Bartleby.com, 2000. Retrieved from: www.bartleby.com/108/ accessed 17 November 2014); 'And if a stranger sojourn with you in your land, you shall not vex him. But the stranger that dwells with you shall be as one born among you, and you shall love him as thyself; for you were strangers in the land of Egypt: "I am the Lord your God"' (Leviticus 19:33-34, The Holy Bible). However, in order for a newcomer such as Ruth to benefit from these laws, the Judean host needs to regard her as a 'stranger' rather than as an infiltrator or illegal alien; the host also needs to choose to uphold the laws.

38 Ruth 1:16-17, The Holy Bible.

39 Ben Naftali, Chronicle of Separation.

40 Kamir, 'Law and Film'.

41 'Lesbian separation' is a term used frequently by Jewish-Israeli lesbians to portray relationship dissolution among lesbian women as an ambiguous event that is anything but linear, progressive or expiring, and that stands for duration, care and endless opportunities for involvement. Lesbian separation is articulated as a common, communal and public property, a predominant feature of lesbian lives, and a central component of lesbian relationality and lesbian identity. See Ruth Preser, 'A Methodology of Damage', International Journal of Social Research Methodology, 19.1 (2016), pp. 17-30.

42 Ruth 4:15.

43 Kamir, 'Law and Film', p. 105.

44 Ruth 4:15.

45 Ruth 2:1.

46 Ruth 2:1.

47 Deuteronomy 24:22.

48 Leviticus 19:9-10.

49 Deuteronomy 24:19-22.

50 Ruth 3:3-5.

51 Kamir, 'Law and Film', p. 116. 
52 Ruth 4:16.

53 Kamir, 'Law and Film', pp. 125-26.

54 Ibid., p. 105.

55 Ibid., p. 115, footnote 94.

56 Ruth 1:16.

57 Daphna Hacker, 'From the Moabite Ruth to Norly the Filipino: Intermarriage and Conversion in the Jewish Nation State', in Gendering Religion and Politics: Untangling Modernities, ed. by Hanna Herzog and Ann Braude (New York: Palgrave Macmillan, 2009), pp. 101-24 (p. 118).

58 Boyarin and Boyarin, 'Diaspora'; Kamir, 'Law and Film'; Raz-Krakotzkin, 'Exile Within Sovereignty'.

59 Raz-Krakotzkin, 'Exile Within Sovereignty'.

60 Boyarin and Boyarin, 'Diaspora'.

61 Ibid., pp. 718 and 720.

62 Raz-Krakotzkin, 'Exile Within Sovereignty'.

63 Sharp, Feminist Queries, pp. 244-45 and 246.

64 Hacker, Moabite Ruth; Ruth Behar, 'A Room Named Ruth', Pakn Treger, 55 (2007), pp. 28-35.

65 Kamir, 'Law and Film', p. 117.

66 Ben Naftali, Chronicle of Separation.

67 Elizabeth Freeman, 'Introduction to "Queer Temporalities”', GLQ: A Journal of Lesbian and Gay Studies, 13 (2007), pp. 159-76, cited in David L. Eng, The Feeling of Kinship: Queer Liberalism and the Racialization of Intimacy (Durham: Duke University Press, 2010), p. 84.

68 Eng, The Feeling of Kinship, p. 84.

69 Susannah Radstone, The Sexual Politics of Time: Confession, Nostalgia, Memory (London: Routledge, 2007).

70 Daniel C. Barber, 'The Immanent Refusal of Conversion', Journal for Cultural and Religious Theory, 13.1 (2014), pp. 142-50.

71 Radstone, The Sexual Politics of Time, p. 30.

72 Ibid., pp. 36-39.

73 Barber, 'Immanent Refusal', p. 150; Radstone, The Sexual Politics of Time, pp. 36-39.

74 Eng, The Feeling of Kinship, pp. 84-85.

75 Judith Butler, Antigone's Claim: Kinship between Life and Death (New York: Columbia University Press, 2000), p. 76.

76 Ibid., p. 78.

77 Brian Keith Axel, 'Digital Figurings of the Unimaginable: Visual Media, Death, and Formations of the Sikh Diaspora', Journal of Ethnic and Migration Studies, 34.7 (2008), pp. 1145-59. 


\section{REFERENCES}

Ahmed, Sara, 'Multiculturalism and the Promise of Happiness', New Formations, 63 (2008), pp. 121-37

Almog, Oz, The Sabra: The Creation of the New Jew, trans. by Haim Watzman (Berkeley: University of California Press, 2000) <https://doi.org/10.1525/california/9780520216426.001. $0001>$

Anzaldúa, Gloria, Borderlands/La Frontera: The New Mestiza (San Francisco: Aunt Lute Books, [1987] 2012)

Aschkenasy, Nehama, 'Reading Ruth through a Bakhtinian Lens: The Carnivalesque in a Biblical Tale', Journal of Biblical Literature, 126.3 (Fall, 2007), pp. 437-53 <https://doi.org/10. $2307 / 27638447>$

Axel, Brian Keith, 'Digital Figurings of the Unimaginable: Visual Media, Death, and Formations of the Sikh Diaspora', Journal of Ethnic and Migration Studies, 34.7 (2008), pp. 1145-59 <https://doi.org/10.1080/13691830802230471>

Barber, Daniel C., 'The Immanent Refusal of Conversion', Journal for Cultural and Religious Theory, 13.1 (2014), pp. 142-50

Boyarin, Daniel and Jonathan Boyarin, 'Diaspora: Generation and the Ground of Jewish Identity', Critical Inquiry, 19.4 (1993), pp. 693-725 <https://doi.org/10.1086/448694>

Butler, Judith, Antigone's Claim: Kinship between Life and Death (New York: Columbia University Press, 2000)

Parting Ways: Jewishness and the Critique of Zionism (New York: Columbia University Press, 2012)

Cavafy, Constantine P., The Canon, trans. by Stratis Haviaras (Athens: Hermes Publishing, 2004)

Eng, David L., The Feeling of Kinship: Queer Liberalism and the Racialization of Intimacy (Durham: Duke University Press, 2010) <https://doi.org/10.1215/9780822392828>

Freeman, Elizabeth, 'Introduction to "Queer Temporalities", GLQ: A Journal of Lesbian and Gay Studies, 13 (2007), pp. 159-76 <https://doi.org/10.1215/10642684-2006-029>

Gilbert, Sandra M., and Susan Gubar, The Madwoman in the Attic: The Woman Writer and the Nineteenth-Century Literary Imagination (New Haven: Yale University Press, [1979] 2000)

Gluzman, Michael, 'Longing for Heterosexuality: Zionism and Sexuality in Herzl's Altneuland', Theory and Criticism, 11 (1997), pp. 145-62 (Hebrew)

Gopinath, Gayatri, Impossible Desires: Queer Diasporas and South Asian Public Cultures (Durham: Duke University Press, 2005) <https://doi.org/10.1215/9780822386537>

Gordon, Avery F., Ghostly Matters: Haunting and the Sociological Imagination (Minneapolis: University of Minnesota Press [1993] 2008)

Hacker, Daphna, 'From the Moabite Ruth to Norly the Filipino: Intermarriage and Conversion in the Jewish Nation State', in Gendering Religion and Politics: Untangling Modernities, ed. by Hanna Herzog and Ann Braude (New York: Palgrave Macmillan, 2009), pp. 101-24 <https://doi.org/10.1057/9780230623378_5> 
Hendershot, Heather, 'Holiness Codes and Holy Homosexuals: Interpreting Gay and Lesbian Christian Subculture', Camera Obscura, 15.3 (2000), pp. 150-93 <https://doi.org/10. 1215/02705346-15-3 45-151>

Kamir, Orit, 'A "Law and Film" Analysis of The Book of Ruth and the Film Antonia's Line', Alei Mishapt Law Review, 8 (2010), pp. 55-132 (Hebrew)

Khazzoom, Aziza, 'The Great Chain of Orientalism: Jewish Identity, Stigma Management, and Ethnic Exclusion in Israel', American Sociological Review, 68.4 (2003), pp. 481-510 $<$ https://doi.org/10.2307/1519736>

Kuntsman, Adi, Figurations of Violence and Belonging: Queerness, Migranthood and Nationalism in Cyberspace and Beyond (Peter Lang: Oxford, 2009)

Masenya, Madipoane, 'Rebecca Alpert's Lesbian Reading of the Book of Ruth within the Context of Lesotho', Journal of Gender and Religion in Africa, 18.1 (2012), pp. 43-62

Naftali, Michal Ben, Chronicle of Separation: On Deconstruction's Disillusioned Love (Tel-Aviv: Resling, 2000) (Hebrew)

Nayar, Pramod K., Contemporary Literary and Cultural Theory: From Structuralism to Ecocriticism (New Delhi: Pearson, 2010)

Preser, Ruth, 'A Methodology of Damage', International Journal of Social Research Methodology, 19.1 (2016), pp. 17-30 <https://doi.org/10.1080/13645579.2014.931202>

Pui-lan, Kwok, Postcolonial Imagination and Feminist Theology (Louisville: Westminster/John Knox Press, 2005)

Radstone, Susannah, The Sexual Politics of Time: Confession, Nostalgia, Memory (London: Routledge, 2007) <https://doi.org/10.4324/9780203937662>

Raz-Krakotzkin, Amnon, 'Exile within Sovereignty: A Critique of the Negation of Exile', Parts I \& II, Theory and Criticism, 4 \& 5 (1993/94), pp. 6-23 / 113-32 (Hebrew)

Rich, Adrienne, 'Compulsory Heterosexuality and Lesbian Existence', Signs: Journal of Women in Culture and Society, 5.4 (1980), pp. 631-60 <https://doi.org/10.1086/493756>

Schimel, Lawrence, 'Diaspora, Sweet Diaspora: Queer Culture to Post-Zionist Jewish Identity', in PoMoSexuals Challenging Assumptions About Gender and Sexuality, ed. by Carol Queen and Lawrence Schimel (San Francisco: Cleiss Press, 1997), pp. 163-73

Sharp, Carolyn J., 'Feminist Queries for Ruth and Joshua: Complex Characterization, Gapping, and the Possibility of Dissent', Scandinavian Journal of the Old Testament: An International Journal of Nordic Theology, 28.2 (2014), pp. 229-52 <https://doi.org/10.1080/ 09018328.2014.932570>

Shenhav, Yehouda and Hannan Hever, “'Arab Jews” after Structuralism: Zionist Discourse and the (De)formation of an Ethnic Identity', Social Identities, 18.1 (2012), pp. 101-18 <https: //doi.org/10.1080/13504630.2011.629517>

Shohat, Ella, 'Sephardim in Israel: Zionism from the Standpoint of Its Jewish Victims', Social Text, 19/20 (1988), pp. 1-35 <https://doi.org/10.2307/466176>

Stahlberg, Lesleigh Cushing, 'Modern Day Moabites: The Bible and the Debate about SameSex Marriage', Biblical Interpretation, 16 (2008), pp. 442-75 <https://doi.org/10.1163/ 156851508X329683>

Weston, Kath, Families We Choose: Lesbians, Gays, Kinship (New York: Columbia University Press, 1991)

Yosef, Raz, 'Melancholic Attachments: Diaspora, Ethnicity, and Sexuality in Contemporary Israeli Cinema', Israeli Sociology: A Journal for the Study of Society in Israel, 15.1 (2013), pp. 1134 (Hebrew) 